\title{
PENGARUH JOB CRAFTING TERHADAP WORK ENGAGEMENT MELALUI PSYCHOLOGICAL MEANINGFULNESS KARYAWAN PT. BOMA BISMA INDRA (PERSERO) SURABAYA
}

\author{
Nofan Darma Syah \\ Universitas Negeri Surabaya \\ Nofansyah16080574011@mhs.unesa.ac.id
}

\begin{abstract}
The purpose of this research was to analyze and examine the effect of job crafting on work engagement through the psychological meaningfulness of employees at PT. Boma Bisma Indra (Persero) Surabaya. This research is causality research with a quantitative approach. The number of samples was 55 employees. Statistical analysis using Partial Least Square with SmartPLS 3.0. The results of the study explained that job crafting has a positive and significant influence on work engagement through psychological meaningfulness as a mediator. In addition, the mediating effect also has a better effect than the direct effect.
\end{abstract}

Keywosrds: job crafting; psychological meaningfulness; work engagement.

\section{PENDAHULUAN}

Revolusi industri 4.0 merupakan era saat ini yang mungkin terus berkembang. Perkembangan zaman saat ini ditandai dengan teknologi dan informasi yang dapat dikatakan menjadi sebuah kebutuhan primer bagi seseorang. Teknologi dan informasi dapat membantu seseorang dalam memenuhi kebutuhan, di antaranya pada bidang ekonomi (Rahayu, 2019). Perubahan ini dapat menyebabkan tuntutan yang harus dipenuhi oleh para pelaku bisnis, pada sektor sumber daya manusia, tuntutan kebutuhan internal perusahaan menjadi salah satu yang harus dipenuhi. Faktor penting sebagai penunjang atas pencapaian suatu cita-cita maupun tujuan perusahaan adalah sumber daya manusia. Selain itu, perkembangan suatu perusahaan juga dapat dipengaruhi oleh sumber daya manusianya, sehingga perlu adanya penyusunan strategi yang tepat untuk mengelolanya dengan cara selama karyawan bekerja tetap memperhatikan keamanan serta kenyamanan, bertujuan supaya rasa keterikatan dengan pekerjaan bisa mereka miliki (Saretta, 2019).

State of Global Workplace menunjukkan hasil laporan atas 115 negara yang telah disurvei, di mana orang dewasa yang jam kerjanya penuh memiliki rata-rata $15 \%$ untuk merasa dirinya terikat oleh pekerjaannya. Hal itu beerarti sebanyak $85 \%$ dari karyawan di seluruh dunia merasa tidak bahagia atau tidak terikat dengan pekerjaan yang dijalani (Integrity Indonesia, 2019). Penelitian yang dilakukan oleh Gallup, salah satu perusahaan konsultasi asal Amerika Serikat juga menyebutkan bahwa di Indonesia karyawan yang merasa dirinya terikat dengan perusahaan hanya sebesar $8 \%$ (Faradila, 2019).

Berdasarkan beberapa fakta di atas, perlunya peningkatan taraf keterikatan karyawan di Indonesia melihat cukup rendahnya karyawan yang merasa dirinya terikat dengan pekerjaannya. Untuk mengelola sumber daya manusia yang kompetitif dan berkompeten, perlu adanya rasa keterikatan kerja oleh karyawan (Ellitan, 2002). Van Wingerden et al., (2017) menyatakan bahwa work engagement mengacu pada keterikatan secara pribadi atas tanggung jawab dan peran mereka secara aktif dalam menjalankan pekerjaannya dengan cara mereka bisa berekspresi secara emosional, kognitif, dan fisik.

Beberapa hal bisa memengaruhi terjadinya work engagement oleh seorang pegawai ialah job crafting (Li \& Yang, 2018). Menurut Meijerink et al., (2018) job crafting adalah jenis pekerjaan proaktif di mana karyawan membentuk pekerjaan yang ditentukan mereka dengan mengubah tugas akan suatu pekerjaan yang mereka lakukan tanpa mengurangi beban dan tanggung jawab untuk membuat suatu kecocokan atas pribadi mereka sendiri. 
Nofan Darma Syah. Pengaruh Job Crafting terhadap Work Engagagement melalui Psychological Meaningfulness Karyawan PT Boma Bisma Bisma Indra (Persero) Surabaya

Tims et al., (2016) mengungkapkan bahwa job crafting mencakup suatu perubahan yang dilakukan oleh seseorang atas pekerjaannya, melakukan pendekatan melalui pekerjaan, atau menjalin interaksi dengan orang lain. Job crafting juga dapat meningkatkan tantangan akan pekerjaan, sumber daya pekerjaan serta menurunkan tuntutan tugas yang dapat menghambat seseorang dalam bekerja. Job crafting dibutuhkan karena pada akhirnya perusahaan akan menerima manfaat dan karyawan akan lebih termotivasi untuk memperoleh hasil yang masimal dalam menyelasaikan pekerjaannya. (Setyawati, 2019).

Keterikatan karyawan bukan hanya dipengaruhi oleh job crafting, tetapi mereka dapat merasa nyaman, terikat, dan terlibat dalam pencapaian tujuan perusahaan yang erat kaitannya dengan kebermaknaan atas pencapaian (Peral \& Geldenhuys, 2016). Chaudhary \& Akhouri (2019) menjelaskan bahwa psychological meaningfulness dapat meningkatkan motivasi dan upaya dalam melakukan suatu pekerjaan untuk menghasilkan sesuatu yang positif dari apa yang dikerjakannya tersebut. Psychological meaningfulness akan dialami oleh seseorang jika mereka telah mempersepsikan hidupnya melalui sebuah perasaan secara emosional yang kuat dalam menyelesaikan sebuah tantangan, berkomitmen dan dia akan totalitas dalam upayanya (Peral \& Geldenhuys, 2016)

Pengaruh psychological meaningfulness terhadap work engagement dibuktikan dalam penelitian Peral \& Geldenhuys (2016) terhadap guru Sekolah Menengah Dasar (SMA) di Afrika Selatan bahwa psychological meaningfulness berpengaruh positif dan memediasi hubungan antara job crafting terhadap work engagement, salah satunya seperti PT. Boma Bisma Indra (Persero) Surabaya lakukan. Keterikatan yang dialami oleh karyawan dipengaruhi oleh beberapa faktor di antaranya adanya kebijakan pemberian reward atas sebuah pencapaian dan hubungan yang baik yang dijalin oleh setiap karyawan akan berdampak positif dan memotivasi karyawan atas kinerjanya. Hal tersebut seperti yang dituturkan salah seorang selaku staff Human Capital, PT. Boma Bisma Indra (Persero) Surabaya, "Terkait dengan work engagement yang dirasakan oleh karyawan banyak dipengaruhi oleh beberapa faktor, di antaranya adalah kenyamanan dalam melakukan pekerjaan, kebijakan pemberian reward terhadap karyawan atas kinerjanya yang secara keseluruhan baik yang dapat dilihat melalui rapot kinerja karyawan dan hubungan yang terjalin baik antar sesama pegawai sehingga dapat membentuk suatu iklim yang positif dalam lingkungan kerja. Di samping itu juga terdapat pegawai yang masa kerjanya lebih dari 15 tahun bahkan sampai dengan masa pensiun. Dalam hal lain, perusahaan melibatkan setiap karyawannya untuk turut andil dalam kegiatan perusahaan.

Penelitian ini bertujuan untuk menguji dan menganalisis bagaimana pengaruh job crafting terhadap work engagament pada karyawan PT Boma Bisma Indra (Persero) Surabaya, menguji dan menganalisis bagaimana pengaruh job crafting terhadap psychological meaningfulness pada karyawan PT Boma Bisma Indra (Persero) Surabaya, menguji dan menganalisis bagaimana pengaruh psychological meaningfulness terhadap work engagement pada karyawan PT Boma Bisma Indra (Persero) Surabaya, serta menguji dan menganalisis bagaimana pengaruh job crafting terhadap work engagament melalui psychological meaningfulness pada karyawan PT Boma Bisma Indra (Persero) Surabaya.

\section{KAJIAN PUSTAKA DAN PENGEMBANGAN HIPOTESIS}

\section{Job Crafting}

Bakker \& Oerlemans (2019) menyatakan bahwa job crafting merupakan suatu kegiatan merangkum perubahan yang dilakukan karyawan secara aktif dalam merancang pekerjaan sendiri, di mana banyak hasil positif dapat hadir sendiri, termasuk kepuasan kerja, keterikatan kerja dan berkembang di tempat kerja. Van Wingerden et al., (2017) berpendapat job crafting adalah sebagai perubahan fisik dan kognitif yang dilakukan individu dalam mengerjakan suatu tugas atau batas relasional pekerjaan mereka. Dalam peneitian ini job crafting menggunakan pendapat dari Peral \& Geldenhuys (2016) sebagai alat ukur penelitian di antaranya adalah increasing structural job resources, decreasing hindering job demands, increasing chalenging job demands dan increasing social job resources. 


\section{Psychological Meaningfulness}

Menurut Ugwu \& Onyishi (2018) mendefinisikan psychological meaningfulness sebagai signifikansi seseorang yang melekat pada suatu objek, peristiwa, atau situasi yang telah ditemukan terkait dengan keterlibatan dalam melakukan pekerjaan. Chaudhary \& Akhouri (2019) berpendapat bahwa psychological meaningfulness mengacu pada suatu keberhasilan dalam melakukan suatu pekerjaan yang erat kaitannya dengan standar dari invidu itu sendiri. Dalam penelitian ini psychological meaningfulness menggunakan pendapat Peral \& Geldenhuys (2016) sebagai alat ukur penelitian yang dibagi menjadi empat indikator yaitu meaning, competence, self determination, dan impact.

\section{Work Engagement}

Wingerden et al., (2018) menjelaskan keterikatan kerja bisa terjadi ketika karyawan secara proaktif mencari tantangan, melibatkan pengalaman dan memotivasi dengan menghasilkan suatu pemecahan masalah yang efektif dalam menyelesaikan pekerjaan. Setyawati (2019) menjelaskan work engagement mengacu pada keterikatan pekerja pada pekerjaan yang dilakukan, dengan cara mempekerjakan mereka untuk bisa beerekspresi secara emosional, fisik, dan kognitif selama mereka bekerja. Hal ini adalah yang disukai seorang pekerja dalam menjalankan pekerjaannya sehingga bisa mendorong koneksi ke pekerjaan, aktif, pribadi (emosional, fisik, dan kognitif), serta orang lain. Albana (2018) menyatakan work engagement diukur melalui 3 indikator yakni vigour, dedication, absorption.

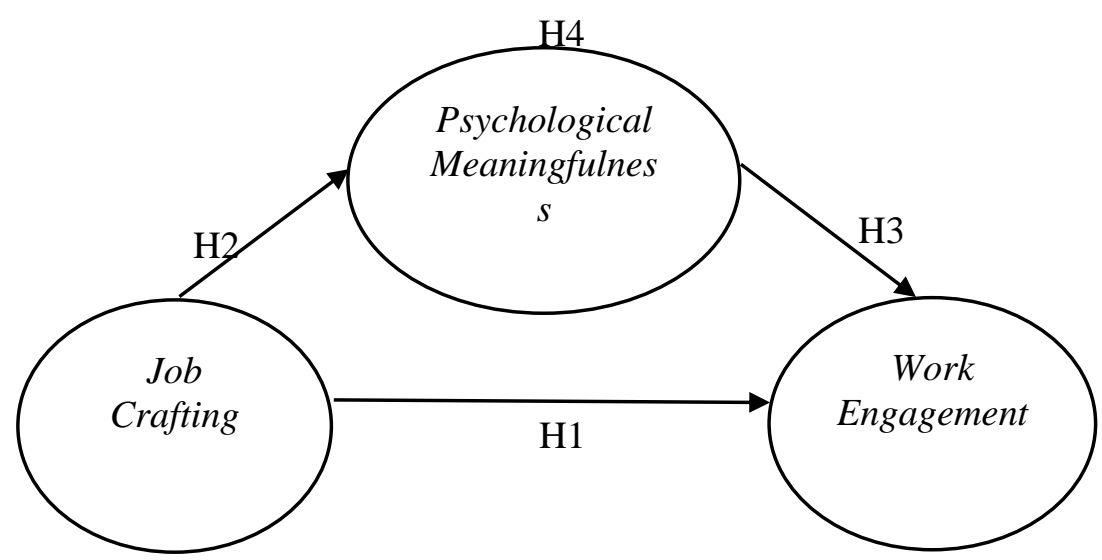

Gambar 1. KERANGKA KONSEPTUAL

\section{Hubungan antar Variabel}

Hubungan antar variabel dapat diamati dalam gambar 1.Van Wingerden et al., (2017) menyatakan bahwa hal yang dapat memengaruhi work engagement yang dirasakan oleh karyawan adalah job crafting. Job crafting mempunyai peran di mana seorang karyawan dalam mengelola pekerjaanya supaya lebih efisien dan efektif. Dalam implementasinya karyawan yang merakan work engagement akan menggunakan pengalaman dan motivasi sebagai manipulasi atas tuntutan pekerjaan dan sumber daya pekerjaan yang diprakarsai oleh karyawan untuk tujuan membuat pekerjaan mereka lebih memuaskan, menarik dan bermakna. Pada penelitian Peral \& Geldenhuys (2016), Tims et al., (2015), Albana (2018), job crafting berpengaruh positif terhadap work engagement.

H1: Diduga work engagement dipengaruhi secara positif oleh job crafting pada karyawan PT. Boma Bisma Indra (Persero) Surabaya.

Van Wingerden et al., (2017) mendefinisikan work engagement sebagai suatu hal yang positif, terkait dengan pekerjaan yang dicirikan oleh kekuatan (vigour), dedikasi (dedication), dan penyerapan (absorption). Job crafting secara positif berhubungan dengan work engagement. Ketika perilaku proaktif muncul akan memunculkan suatu konsekuensi interpersonal yang sangat penting dan secara tidak langsung akan memengaruhi work engagement (Morrow \& Conger, 2018). Penelitian oleh Peral \& Geldenhuys (2016) menyatakan bahwa psychological meaningfulness memiliki hubungan yang 
Nofan Darma Syah. Pengaruh Job Crafting terhadap Work Engagagement melalui Psychological Meaningfulness Karyawan PT Boma Bisma Bisma Indra (Persero) Surabaya

positif terhadap job crafting. Sejalan dengan penelitian yang dilakukan oleh Tims et al., (2016) menemukan bahwa adanya hubungan positif antara psychological meaningfulness terhadap job crafting.

H2: Diduga psychological meaningfulness dipengaruhi positif oleh job crafting pada karyawan PT. Boma Bisma Indra (Persero) Surabaya.

Chaudhary \& Akhouri (2019) menjelaskan bahwa psychological meaningfulness mengacu pada nilai yang mengacu pada suatu keberhasilan dalam melakukan suatu pekerjaan yang erat kaitannya dengan standar dari individu itu sendiri, sehingga semakin tinggi psychlogical meaningfulness maka semakin tinggi pula work engagement. Hal tersebut didukung oleh penelitian yang dilakukan Bakker \& Bal (2010) menyatakan bahwa psychological meaningfulness berhubungan positif dengan work engagent. Sejalan dengan penelitian Costantini \& Sartori (2018) menemukan bahwa psychological meaningfulness berhubungan positif dengan work engagement.

H3: Diduga work engagement dipengaruhi secara positiff oleh psychological meaningfulness pada karyawan PT. Boma Bisma Indra (Persero) Surabaya.

Ugwu \& Onyishi (2018) berpendapat bahwa suatu rasa kepuasan yang dapat timbul dari dalam diri seseorang sebagai suatu signifikansi atas suatu pekerjaan yang mereka lakukan. Peral \& Geldenhuys (2016) mendapati bahwa variabel psychological meaningfulness mampu memediasi pengaruh job crafting terhadap work engagement pada guru Sekolah Menengah Atas (SMA) di Afrika Selatan. Hasil penelitian tersebut menyatakan bahwa semakin tinggi psychological meaningfulness yang dirasakan oleh karyawan dari adanya penerapan job crafting sebagai manupulasi akan tuntutan tugas tanpa mengurangi beban dan tanggung jawab mereka dalam melakukan pekerjaan yang nantinya akan meningkatkan work engagement.

H4: Diduga psychological meaningfulness memediasi job crafting terhadap work engagement pada karyawan PT. Boma Bisma Indra (Persero) Surabaya.

\section{METODE PENELITIAN}

Jenis penelitian kuantitatif digunakan pada penelitian ini dengan lokasi penelitian bertempat di PT. Boma Bisma Indra (Persero) Surabaya. Penyebaran kuesioner, wawancara secara tidak terstruktur maupun terstruktur, serta hasil observasi dilakukan untuk mengumpulkan data. Karyawan tetap dalam penelitian ini dijadikan sebagai populasi. Awalnya sampel jenuh dijadikan sebagai teknik pengambilan sampel, namun realita di lapangan kuesioner yang berhasil terisi dan terkumpul sebanyak 55 responden dari 79 responden. Skala likert 1-5 sijadikan sebagai skala pengukuran, serta Structural Equation Modelling (SEM) dan menggunakan bantuan software Partial Least Square (PLS) versi 3.0 merupakan teknik analisis datanya.

\section{HASIL DAN PEMBAHASAN}

\section{Convergent Validity}

Hasil seluruh indikator dapat dinyatakan valid bila mempunyai outer loading di atas 0,70 , menurut hasil nilai yang ditunjukkan oleh gambar 2 setiap variabel yang dijelaskan oleh masing-masing indikator telah memenuhi syarat di mana nilai loading factor $>0,50$ dan dinyatakan valid (Ghozali, I., \& Latan, 2015).

\section{Composite Reliability \& Cronbach Alpha's}

Berdasarkan tabel 1 dapat diartikan bahwa variabel job crafting memiliki nilai 0,881 lebih dari 0,70 sehingga konstruk ini memiliki reliablitias tinggi. Variabel psychological meaningfulness mempunyai nilai 0,889 yang tergolong memiliki nilai reliabilitas tinggi karena bernilai di atas 0,70 . Sedangkan variable work engagement bernilai 0,915 yang berarti variabel ini memiliki nilai reliabilitas yang 
tinggi karena memiliki di atas nilai 0,70. Artinya, semua variabel konstruk dianggap mempunyai composite reliability sangat baik.

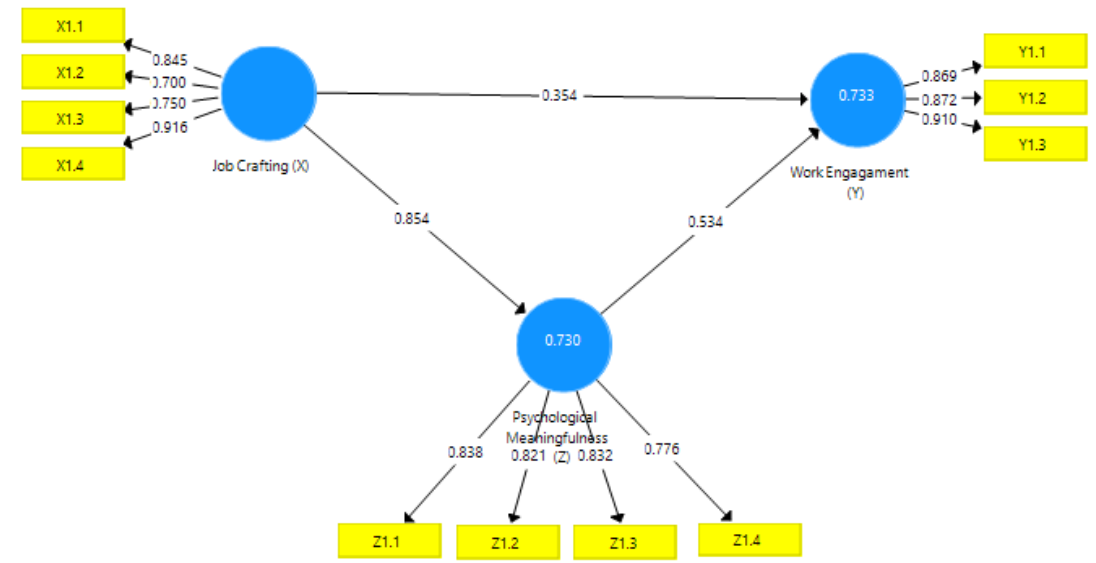

Sumber: Output Smart PLS 3.0, 2020

Gambar 2. UJI MEASUREMENT MODEL

Tabel 1. COMPOSITE RELIABILITY DAN CRONBACH'S ALPHA

\begin{tabular}{lcc}
\hline \multicolumn{1}{c}{ Variabel } & Composite Reliability & Cronbach's Alpha \\
\hline Job Crafting & 0,881 & 0,821 \\
Psychological Meaningfulness & 0,889 & 0,834 \\
Work Engagament & 0,915 & 0,860 \\
\hline
\end{tabular}

Sumber: Output Smart PLS 3.0 (2020)

\section{Analisis R-Square}

Nilai $R$-square yang dapat dihasilkan dari output SmartPLS 3.0 dapat dilihat di Tabel 2. Square. Dalam kata lain, nilai tersebut mampu menjelaskan bahwa variabel kontruk work engagement sanggup dijelaskan oleh $73,3 \%$ variabel job crafting, dan variabel-variabel lain yang tidak termasuk dalam penelitian ini sebesar 26,7\%. Berdasar tabel 2 work engagement dipengaruhi oleh job crafting memberikan nilai 0,733 untuk R-Square. Kemudian pada tabel 2, menunjukkan pengaruh job crafting terhadap psychological meaningfulness memberikan nilai R-Square sebesar 0,730 yang menunjukkan bahwa variabel kontruk psychological meaningfulness dapat dijelaskan oleh $73 \%$ variabel job crafting, sedangkan variabel-variabel lain yang tidak diteliti dalam penelitian ini $27 \%$ sanggup menjelaskan psychological meaningfulness.

Tabel 2.

\section{R-SQUARE}

\begin{tabular}{lc}
\hline \multicolumn{1}{c}{ Variabel } & R-Square \\
\hline Psychological Meaningfulness & 0,730 \\
Work Engagement & 0,733 \\
\hline Sumber: Output Smart PLS 3.0 (2020)
\end{tabular}

\section{Uji Relevansi Prediksi}

Model PLS dapat dievaluasi dengan mengamati R-Square dan $Q$-Square predictive relevance. Hasil perhitungan uji relevansi prediksi memperoleh nilai $Q$-Square predictive relevance 0,787 , yang berarti nilai $>0$. Artinya, predictive relevance dapat menjelaskan model sebesar $78 \%$. 
Nofan Darma Syah. Pengaruh Job Crafting terhadap Work Engagagement melalui Psychological Meaningfulness Karyawan PT Boma Bisma Bisma Indra (Persero) Surabaya

\section{Uji Kausalitas}

Penelitian ini menggunakan Inner model sebagai penganalisaan nilai signifikan pada tabel path coefficient dan pengaruh suatu konstruk, serta gambar pada hasil Indirect Effects seperti Gambar 3.

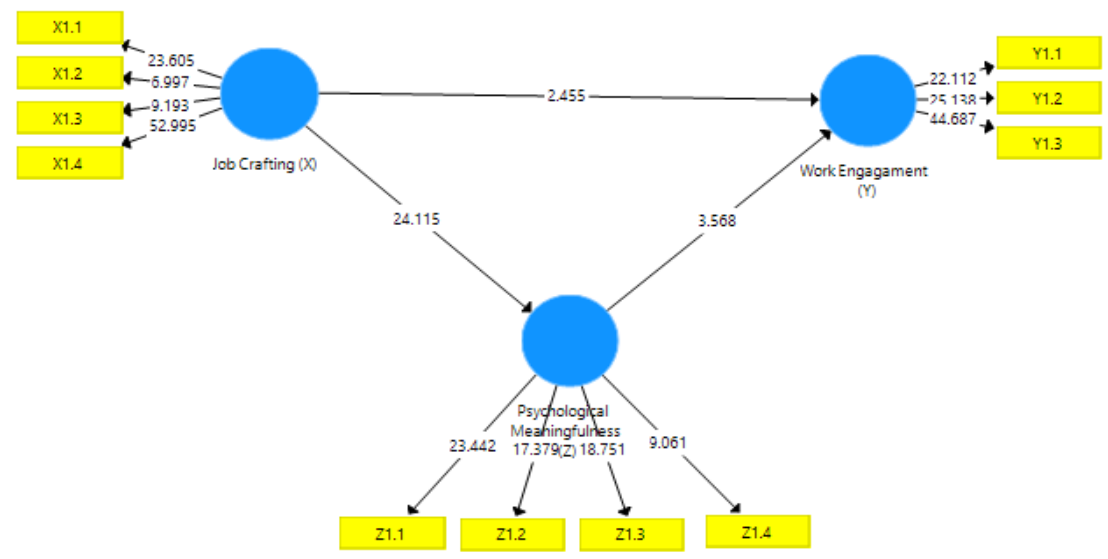

Sumber: Output Smart PLS 3.0, 2020

Gambar 3. UJI MEASUREMENT BOOSTRAPING MODEL

Tabel 3.

PATH COEFFICIENTS \& INDIRECT EFFECT

\begin{tabular}{ccccc}
\hline Diagram Path & $\begin{array}{c}\text { Original } \\
\text { Sampel }\end{array}$ & $\begin{array}{c}\text { T- } \\
\text { Statistics }\end{array}$ & Keterangan \\
\hline Job Crafting $\rightarrow$ Psychological & 0,854 & 24,115 & $\geq 1,96$ (Signifikan) & Hipotesis diterima \\
Meaningfulness & 0,354 & 2,455 & $\geq 1,96$ (Signifikan) & Hipotesis diterima \\
$\begin{array}{c}\text { Job Crafting } \rightarrow \text { Work Engagement } \\
\text { Psychological Meaningfulness } \rightarrow\end{array}$ & 0,534 & 3,568 & $\geq 1,96$ (Signifikan) & Hipotesis diterima \\
$\begin{array}{c}\text { Work Engagement } \\
\text { Job Crafting } \rightarrow \text { Psychological }\end{array}$ & 0,456 & 3,498 & $\geq 1,96$ (Signifikan) & Hipotesis Diterima \\
Meaningfulness $\rightarrow$ Work Engagement & & & & \\
\hline
\end{tabular}

Sumber: Output Smart PLS 3.0 (2020)

Berdasarkan pada tabel 3 dampak job crafting terhadap psychologcal meaningfulness dengan nilai angka t-statistik sejumlah 24,115 > 1,96. Hal tersebut menjelaskan bahwa antara variabel job crafting dan psychological meaningfulness berpengaruh secara signifikan. Sementara itu, angka original sampel yaitu 0,854 yang menunjukkan tanda positif dan bermakna semakin baik job crafting dengan demikian akan bertambah baik pula psychological meaningfulness, begitu pula sebaliknya.

Selanjutnya, dampak job crafting terhadap work engagement dengan angka t-statistik sejumlah 2,455 $>$ 1,96. Hal tersebut menjelaskan bahwa antara variabel job crafting dan work engagement berpengaruh secara signifikan. Sementara itu, angka original sampel yaitu 0,354 yang menunjukkan tanda positif dan bermakna semakin baik job crafting dengan demikian akan bertambah baik pula work engagement, begitu pula sebaliknya.

Kemudian pengaruh psychological meaningfulness terhadap work engagement dengan nilai angka tstatistik sejumlah 3,568 >1,96. Hal tersebut menjelaskan bahwa antara variabel psychological meaningfulness dan work engagement berpengaruh secara signifikan. Sementara itu, angka original sampel yaitu 0,534 yang menunjukkan tanda positif dan bermakna semakin baik psychological meaningfulness dengan demikian akan bertambah baik pula work engagement, begitu pula sebaliknya.

Sementara itu, dampak job crafting terhadap work engagament melalui psychologcal meaningfulness dengan angka t-statistik sejumlah 3,498 > 1,96. Hal tersebut menjelaskan bahwa variabel psychological meaningfulness memediasi antara job crafting dan work engagement. 


\section{Pengaruh Job Crafting terhadap Work Engagement karyawan PT. Boma Bisma Indra (PERSERO) Surabaya}

Hasil analisis PLS menyatakan job crafting secara positif dipengaruhi oleh work engagament. Melalui hasil observasi dan wawancara yang dilakukan dengan salah satu bagian staf Manager Bidang Remunerasi \& Personalia PT. Boma Bisma Indra (PERSERO) Surabaya menjelaskan bahwa beliau merasa sudah menerapkan job crafting dengan baik begitu pula dengan rekan staf yang lain terutama di bagian umum dan personalia. Beliau juga beranggapan bila job crafting dilakukan dengan baik maka nantinya akan menimbulkan suatu dampak yang positif, efektif dan efesien dalam menyelesaikan suatu pekerjaan sehingga pekerjaan dapat menimbulkan rasa keterlibatan bekerja.

Selain itu, setiap karyawan juga memiliki target masing-masing yang harus dicapai. Untuk mencapai target tersebut karyawan harus mampu mengendalikan diri dengan baik. Karyawan dapat bertanggung jawab terhadap setiap tindakannya. Setiap karyawan memiliki rasa optimisme yang tinggi dalam membuat sebuah keputusan.

Hasil penelitian ini membuktikan bahwa work engagement dipengaruhi secara positif dan signifikan oleh job crafting. Sehingga, secara langsung atau tidak karyawan telah menerapkan job crafting untuk mendukung menyelesaikan pekerjaannya yang berbanding lurus dengan keterikatan yang dirasakan oleh karyawan. Hal tersebut disebabkan karena sikap dan persepsi dari setiap karyawan atas pekerjaan yang mereka tekuni. Hasil ini mendukung penelitian dari Peral \& Geldenhuys (2016), Van Wingerden et al., (2017) dan Morrow \& Conger (2018) menyatakan bahwa work engagement dan job crafting terdapat hubungan yang positif. Namun penelitian dengan hasil yang berbeda dilakukan oleh Petrou $e t$ al., (2017) menyatakan bahwa work engagement tidak berpengaruh terhadap job crafting.

Berdasarkan hasil wawancara diketahui karyawan PT. Boma Bisma Indra (Persero) Surabaya memiliki ikatan pekerjaan yang kuat. Hal tersebut dibuktikan dengan data yang menunjukkan karyawan yang bekerja disana sampai pensiun dan juga banyak yang di atas 10-15 tahun.

\section{Pengaruh Job Crafting terhadap Psychological Meaningfulness karyawan PT. Boma Bisma Indra (PERSERO) Surabaya}

Job crafting membawa pengaruh pada psychological meaningfulness jika dilihat dari hasil penelitian. Berdasarkan hasil wawancara dengan salah satu karyawan bagian staf Sekretaris Perusahaan PT. Boma Bisma Indra (Persero) Surabaya menjelaskan bahwa sebelum mengerjakan pekerjaannya, beliau lebih dulu menentukan pekerjaan yang menurut beliau lebih mudah dalam menyelesaikannya. Tidak jarang juga beliau mengerjakan pekerjaan yang sifatnya penting terlebih dahulu, sehingga beliau menyelesaikan tugas beliau tepat waktu bahkan sebelum waktunya sudah selesai sehingga beliau dapat menyelesaikan pekerjaan yang lainnya.. Hal tersebut juga disampaikan salah satu karyawan dari bagian staf Sumber Daya Manusia beliau merasa harus menyelesaikan pekerjaan yang menurut beliau lebih mudah untuk selesaikan. Dari hasil wawancara tersebut dapat disimpulkan bahwa dengan menyelesaikan tugas yang sekiranya mudah dan dapat dikerjakan dalam satu waktu terlebih dahulu merupakan salah satu faktor stimulus seseorang merasakan psychological meaningfulnesss.

Hasil penelitian ini membuktikan bahwa psychological meaningfulness dipengaruhi secara positif oleh job crafting. Artinya, semakin tinggi psychological meaningfulness jika semakin tinggi pula job crafting. Hal tersebut mendukung penelitian dari Costantini \& Sartori (2018) dalam penelitiannya yang menyebutkan bahwa psychological meaningfulness dapat dipengaruhi oleh job crafting. Hasil tersebut selaras dengan penelitian dari Tims et al., (2016) yang terbukti bahwa peningkatan kesejahteraan karyawan bisa dipengaruhi dari job crafting yang berjalan dengan baik, dengan demikian maka dapat disimpulkan, tingginya job crafting karyawan PT. Boma Bisma Indra (Persero) Surabaya akan sangat memengaruhi psychological meaningfulness karena jika semua karyawan memiliki tanggung jawab yang tinggi dalam hal pengelolaan terkait design pekerjaan yang dilakukan maka secara tidak langsung karyawan telah memikirkan bagaimana menyelesaikan pekerjaan yang telah menjadi tanggung jawabnya dengan efisien serta efektif. 
Nofan Darma Syah. Pengaruh Job Crafting terhadap Work Engagagement melalui Psychological Meaningfulness Karyawan PT Boma Bisma Bisma Indra (Persero) Surabaya

\section{Pengaruh Work Engagement terhadap Psychological Meaningfulness karyawan PT. Boma Bisma Indra (PERSERO) Surabaya}

Hasil analisis PLS diketahui bahwa work engagement positif terhadap work engagement. Hal ini berarti work engagement dipengaruhi secara signifikan dan positif oleh psychological meaningfulness. Jika semakin tinggi work engagement, maka semaikin tinggi pula psychological meaningfulness, hal tersebut berbanding lurus dan mendukung Peral \& Geldenhuys (2016) yang menunjukkan bahwa work engagement bisa dipengaruhi oleh psychological meaningfulness. Lalu penelitian dari Costantini \& Sartori (2018) menyatakan bahwa psychological meaningfulness sangat penting untuk mempertahankan ketahanan selama kondisi kerja yang penuh tekanan dan yang menyatakan psychological meaningfulness telah terbukti berkontribusi secara signifikan terhadap hasil yang terkait dengan pekerjaan. Dengan demikian, karyawan dari PT. Boma Bisma Indra (Persero) Surabaya bisa meningkatkan work engagement mereka diakibatkan dari tingginya psychological meaningfulness.

Apabila dikaitkan dengan hasil observasi dan wawancara dengan salah satu karyawan bagian staf sekretaris Perusahaan PT. Boma Bisma Indra (PERSERO) Surabaya menjelaskan bahwa menurut beliau dalam bekerja harus merasa bekerja secara profesional, dalam artian tidak boleh mencampurkan antara urusan pribadi dengan pekerjaan. Karena dapat berdampak kurang baik menurut beliau. Hal tersebut juga disampaikan oleh salah satu karyawan dari bagian staf Sumber Daya Manusia beliau merasa nyaman dengan pekerjaannya, terlebih beliau menyatakan diberikan kesempatan dan tanggung jawab sesuai dengan passion yang beliau jalani selama ini. Begitupula dengan hasil wawancara dengan karyawan bagian staf Sekretaris Perusahaan PT. Boma Bisma Indra (PERSERO) Surabaya yang menjelaskan bahwa menurut beliau lingkungan kerjanya memiliki efek yang positif, dalam artian beliau memiliki rekan kerja yang supportif satu sama lain sehingga terjalin suatu rasa kebersamaan sehingga beliau merasa puas dalam bekerja karena memiliki rekan kerja yang mendukung.

\section{Pengaruh Job Crafting melalui Psychological Meaningfulness terhadap Work Engagement karyawan PT. Boma Bisma Indra (PERSERO) Surabaya}

Hasil pengujian hipotesis menunjukkan bahwa psychological meaningfulness memiliki peran mediasi antara job crafting dan work engagement. Jika dikaitkan dalam penelitian untuk mencapai work engagament, karyawan harus memenuhi beberapa faktor di antaranya kompetensi, kapabilitas, dedikasi, dan rasa nyaman atas pekerjaannya. Dari hal tersebut sangat penting dimiliki oleh setiap karyawan di mana hal itu menjadi salah satu faktor pendukung agar karyawan dapat bekerja dengan efisien dan efektif sehingga dapat mencapai tujuan bersama.

Menurut hasil observasi dan wawancara yang dilakukan di PT. Boma Bisma Indra (PERSERO) Surabaya dengan salah satu karyawan staf Manager Bidang Remunerasi \& Personalia, staf sekretaris dan staf Sumber Daya Manusia yang mengatakan bahwa semua karyawan sudah dirasa menerapkan job crafting secara langsung maupun tidak langsung, karena karyawan didalam perusahaan sudah sadar akan tanggung jawab pekerjaan yang dilakukan dan membuat segala keadaan menjadi kondusif serta nyaman bagi seluruh pekerja yang bekerja di seluruh divisi.

Work engagement karyawan terbukti dipengaruhi secara langsung dan tidak langsung oleh psychological meaningfulness, namun efek mediasi memiliki nilai yang lebih baik daripada efek secara langsung di mana efeknya meningkat dengan mediator. Analisis penelitian ini dapat memberikan informasi bahwa psychological meaningfulness memediasi hubungan antara pengaruh job crafting terhadap work engagament. Seperti halnya pada penelitian sebelumnya yang dilakukan oleh Peral \& Geldenhuys (2016) di mana psychological meaningfulness dapat menjadi variabel mediasi antara job crafting dan work engagement.

\section{KESIMPULAN}

Berdasarkan uraian hasil analisis maka kesimpulan yang dapat diambil ialah Job crafting secara signifikan positif berpengaruh pada work engagement, Job crafting secara signifikan positif memengaruhi psychological meaningfulness, Psychological meaningfulness secara signifikan positif 
memengaruhi work engagement, dan psychological meaningfulness memediasi antara work engagement dengan job crafting. Implikasi manajerial pada penelitian ini bahwa PT. Boma Bisma Indra (Persero) Surabaya perlu terus meningkatkan serta mempertahankan penerapan karyawan dalam job crafting dan psychological meaningfulness supaya memiliki karyawan yang tinggi work engagement nya. Selain itu perusahaan juga perlu meningkatkan rasa percaya diri untuk melakukan hal diluar kemampuan karyawan pada saat bekerja. Hal tersebut dapat dilakukan dengan adanya umpan balik atau interaksi dengan atasan yang baik, sebagai contoh hasil pekerjaan yang bagus diberikan apresiasi hal ini berguna supaya karyawan merasa dirinya dihargai. Membuat dengan jelas dan mudah dipahami job description masing-masing bagian. Selain itu atasan juga perlu untuk memberitahu batas wewenang dari karyawan dalam mengabil keputusan.

Penelitian ini memiliki keterbatasan dari penggunaan sampel yang belum maksimal yaitu sebanyak 55 orang karyawan, hal ini disebabkan oleh adanya sistem shift kerja dan Work From Home (WFH) yang dilakukan perusahaan. Penelitian selanjutnya dapat menggunakan sampel penelitian dan menggunakan objek perusahaan swasta agar memunculkan pemahaman baru mengenai sistem dari variabel yang digunakan dari perusahaan tersebut, serta dapat menambah variabel lain seperti job satisfaction untuk menggambarkan work engagement dalam suatu perusahaan.

\section{DAFTAR PUSTAKA}

Albana, H. (2018). Pengaruh Job Crafting Terhadap Kinerja Karyawan Yang Dimediasi Oleh Work Engagement Di Pt. Terminal Teluk Lamong, Surabaya. Jurnal Ilmu Manajemen (JIM), 7(1), 210-219.

Bakker, A. B., \& Bal, P. M. (2010). Weekly work engagement and performance: A study among starting teachers. Journal of Occupational and Organizational Psychology, 83(1), 189-206. https://doi.org/10.1348/096317909X402596

Bakker, A. B., \& Oerlemans, W. G. M. (2019). Daily job crafting and momentary work engagement: A self-determination and self-regulation perspective. Journal of Vocational Behavior, 112(December 2018), 417-430. https://doi.org/10.1016/j.jvb.2018.12.005

Chaudhary, R., \& Akhouri, A. (2019). CSR perceptions and employee creativity: examining serial mediation effects of meaningfulness and work engagement. Social Responsibility Journal, 15(1), 61-74. https://doi.org/10.1108/SRJ-01-2018-0018

Costantini, A., \& Sartori, R. (2018). The Intertwined Relationship Between Job Crafting, WorkRelated Positive Emotions, and Work Engagement. Evidence from a Positive Psychology Intervention Study. The Open Psychology Journal, 11(1), 210-221. https://doi.org/10.2174/1874350101811010210

Ellitan, L. (2002). Praktik-Praktik Pengelolaan Sumber Daya Manusia Dan Keunggulan Kompetitif Berkelanjutan. Jurnal Manajemen Dan Wirausaha, 4(2), 65-76. https://doi.org/10.9744/jmk.4.2.pp.65-76

Faradila, R. (2019). Top Employe Engagement Trends in 2019. Retrieved August 20, 2019, from 06 April 2019 website: https://jtanzilco.com/blog/detail/1300/slug/top-employee-engagementtrends-in-2019

Ghozali, I., \& Latan, H. (2015). Partial Least Squares Konsep, Teknik dan Aplikasi Menggunakan Program SmartPLS 3.0 Untuk Penelitian Empiris. Semarang: Badan Penerbit Universitas Diponegoro.

Integrity Indonesia. (2019). 85\% Karyawan Di Dunia Tak Bahagia Dengan Pekerjaannya. Retrieved 
Nofan Darma Syah. Pengaruh Job Crafting terhadap Work Engagagement melalui Psychological Meaningfulness Karyawan PT Boma Bisma Bisma Indra (Persero) Surabaya

August 25, 2019, from 2019 website: https://www.integrityindonesia.com/id/blog/2018/03/06/85-karyawan-di-dunia-tak-bahagia-dengan-pekerjaannya/

Li, H., \& Yang, X. (2018). When a calling is living: Job crafting mediates the relationships between living a calling and work engagement. Journal of Chinese Human Resource Management, 9(2), 77-106. https://doi.org/10.1108/JCHRM-12-2017-0030

Meijerink, J., Bos-Nehles, A., \& de Leede, J. (2018). How employees' pro-activity translates highcommitment HRM systems into work engagement: the mediating role of job crafting. International Journal of Human Resource Management, 5192, 1-26. https://doi.org/10.1080/09585192.2018.1475402

Morrow, D., \& Conger, S. (2018). Job Crafting, Mindfulness, Meaningfulness, and Work Engagement. 3rd International Symposium on Meaningful Work, Amsterdam, The Netherlands, (March), (May), 1-7. Retrieved from www.researchgate.net/profile/Donna_Morrow2

Peral, S., \& Geldenhuys, M. (2016). The effects of job crafting on subjective well-being amongst south African high school teachers. SA Journal of Industrial Psychology, 42(1), 1-13. https://doi.org/10.4102/sajip.v42i1.1378

Petrou, P., Bakker, A. B., \& van den Heuvel, M. (2017). Weekly job crafting and leisure crafting: Implications for meaning-making and work engagement. Journal of Occupational and Organizational Psychology, 90(2), 129-152. https://doi.org/10.1111/joop.12160

Rahayu, N. (2019). Mengenal Revolusi Industri dari 1.0 hingga 4.0. Retrieved June 10, 2020, from Wartaekonomi.com website: https://www.wartaekonomi.co.id/read226785/mengenal-revolusiindustri-dari-10-hingga-40

Saretta, I. R. (2019). Manajemen Sumber Daya Manusia Sebagai Upaya Mencapai Target Organisasi. Retrieved June 11, 2020, from cermati.com website: https://www.cermati.com/artikel/manajemen-sumber-daya-manusia-sebagai-upaya-mencapaitarget-organisasi

Setyawati, S. M. (2019). Praktik sdm, job crafting dan work engagement terhadap kinerja karyawan. Jurnal Ilmu Manajemen (JIM), 7(3), 619-628.

Tims, M., Bakker, A. B., \& Derks, D. (2015). Job crafting and job performance: A longitudinal study. European Journal of Work and Organizational Psychology, 24(6), 914-928. https://doi.org/10.1080/1359432X.2014.969245

Tims, M., Derks, D., \& Bakker, A. B. (2016a). Job crafting and its relationships with person-job fit and meaningfulness: A three-wave study. Journal of Vocational Behavior, 92, 44-53. https://doi.org/10.1016/j.jvb.2015.11.007

Tims, M., Derks, D., \& Bakker, A. B. (2016b). Job crafting and its relationships with person - job fi t and meaningfulness: A three-wave study. Journal of Vocational Behavior, 92, 44-53. https://doi.org/10.1016/j.jvb.2015.11.007

Ugwu, F. O., \& Onyishi, I. E. (2018). Linking Perceived Organizational Frustration to Work Engagement: The Moderating Roles of Sense of Calling and Psychological Meaningfulness. Journal of Career Assessment, 26(2), 220-239. https://doi.org/10.1177/1069072717692735

Van Wingerden, J., Derks, D., \& Bakker, A. B. (2017). The Impact of Personal Resources and Job Crafting Interventions on Work Engagement and Performance. Human Resource Management, 56(1), 51-67. https://doi.org/10.1002/hrm.21758 
Wingerden, J. Van, Stoep, J. Van der, \& Poell, R. (2018). Meaningful Work and Work Engagement: The Mediating Role of Perceived Opportunities to Craft and Job Crafting Behavior. International Journal of Human Resource Studies, 8(2), 1. https://doi.org/10.5296/ijhrs.v8i2.12635 